\title{
Cultivation of three color strains of Gracilaria domingensis in an integrated organic system
}

\author{
Thiago Gaban Trigueiro • Dinaelza Castelo Pereira • Aline P. Martins • \\ Pio Colepicolo $\cdot$ Eliane Marinho-Soriano
}

Received: 17 March 2017/Accepted: 27 July 2017/Published online: 2 August 2017

(C) The Author(s) 2017. This article is an open access publication

\begin{abstract}
Species of the genus Gracilaria are widely distributed around the world, and many are wild harvested and cultivated for phycocolloid production (agar) and human food. This study investigated the growth performance of three color strains of Gracilaria domingensis in an integrated organic system. The three chromatic variants (red, green, and brown) were cultured in a shrimp farm at two depths (surface and $20 \mathrm{~cm}$ ). The highest relative growth rates were obtained in the first week of cultivation for all three strains studied. Although the growth rates and biomass were slightly higher at a depth of $20 \mathrm{~cm}$, significant differences were not observed at different depths $(p<0.05)$. The growth of the three strains varied significantly over time $(p<0.001)$. The maximal growth values obtained were $11.25 \pm 1.50 \% \mathrm{day}^{-1}$ (red), $12.76 \pm 3.96 \% \mathrm{day}^{-1}$ (green), and $7.86 \pm 1.75 \% \mathrm{day}^{-1}$ (brown). The mean growth rates for the whole period were $4.63 \pm 6.97,3.38 \pm 9.09$, and $2.16 \pm 6.61 \%$ day $^{-1}$ for the red, green, and brown strains, respectively. The pigment content (chlorophyll $a$, phycocyanin, and phycoerythrin) of the three strains studied was higher at a depth of $20 \mathrm{~cm}$, while the maximum electron transport rate $\left(E R_{\max }\right)$ and photosynthetic efficiency were higher at the surface. The high growth rates obtained in this study demonstrate the great potential of this species for integrated organic farming. Moreover, the ecological success shown by the red strain suggests that this strain is the most suitable for integrated cultivation.
\end{abstract}

Keywords Gracilaria domingensis · Cultivation · Biomass · Growth · Pigment composition

\section{Introduction}

Gracilaria species are notable for their economic importance in the production of agar, human food, animal feed, fertilizer, drugs, and biofuel (Buchholz et al. 2012). With a cosmopolitan distribution and high growth rates, these species are considered good candidates for cultivation in various parts of the world (Yarish and Pereira 2008). Several Gracilaria species have been cultivated on a large scale in many countries, which has been mainly attributed to high growth rates and easy vegetative propagation. Another remarkable feature of

T. G. Trigueiro - D. C. Pereira · E. Marinho-Soriano $(\bowtie)$

Department of Oceanography and Limnology, Federal University of Rio Grande do Norte, Via Costeira, Praia de Mãe Luiza, s/n, Natal, RN 59014-002, Brazil

e-mail: eliane@ufrnet.br

A. P. Martins - P. Colepicolo

Department of Biochemistry, São Paulo University, Av. Prof. Lineu Prestes, 748, São Paulo, SP 05508-000, Brazil 
this genus is the ability of certain species to absorb and store high nutrient concentrations, so it has been recognized of aquacultural wastewaters (Marinho-Soriano et al. 2009).

Success in cultivating seaweed depends on knowledge of the ecophysiological characteristics of the species and how important factors for seaweed growth can be manipulated to improve yields (Harrison and Hurd 2001). Moreover, a farming establishment must use strains tolerant to environmental conditions. Strain selection should be based on such important criteria as adaptability to a wide variety of environmental factors, high growth rates, nutrient removal efficiency, and economic potential (Neori et al. 2004). The response to different environmental parameters can assist in the selection of a particular strain for mariculture.

Gracilaria is a genus of red algae highly adaptive to variation in environmental conditions, so it can be cultivated in both sea- and land-based aquaculture systems (Neori et al. 2004). Integrated multi-trophic aquaculture (IMTA) has been shown to be a very promising method for seaweed production. This practice is based on the use of one species' waste to provide food for another (Chopin et al. 2008; Wu et al. 2015). In such systems, the seaweed utilizes the animals' metabolic waste as fertilizer while absorbing $\mathrm{CO}_{2}$ and releasing $\mathrm{O}_{2}$ to the environment. The seaweed of economic potential cultivated in IMTA is doubly interesting, since it reduces environmental impact and provides biomass for the extraction of high-value compounds (Samocha et al. 2015; Yu et al. 2016; Barceló-Villalobos et al. 2017). In addition, IMTA has the potential to contribute to a positive, sustainable image, and improved social acceptability (Barrington et al. 2010).

Organic aquaculture is another approach that has been shown to be an effective method for supporting sustainable aquaculture and providing economic benefits. This activity has emerged as an alternative to conventional aquaculture and is differently aimed at the economic, ecological, and farming potentials of other organisms (fish, oysters, seaweed, etc.). This practice improves the ecological state of the ponds and avoids negative impacts to the environment (Bergleiter 2011).

In Brazil, shrimp (Litopenaeus vannamei) farming is the most economically successful segment of the aquaculture industry. Shrimp are predominantly cultivated under semi-intensive aquaculture systems. Shrimp farms are concentrated in the northeast of Brazil, which accounts for approximately $90 \%$ of national production. In contrast, cultivation of seaweed is still in its early stage and has been limited to the exploitation of wild seaweed for phycocolloid extraction (agar and carrageenan). Seaweed (Gracilaria and Hypnea) is mainly harvested by women and young people during low tide and is an important source of income for coastal communities (Marinho-Soriano 2017).

Natural populations of Gracilaria have three color variants with different pigmentations: green, red, and brown. Differences in their physiological characteristics, including growth, pigments, photosynthesis, and polysaccharides, have been reported in laboratory studies (Ayres-Ostrock and Plastino 2014; Faria and Plastino 2016). However, few studies have focused on the growth performance of color variants under field cultivation (Ursi et al. 2013; Veeragurunathan et al. 2016).

The species $G$. domingensis is widely distributed, occurring along almost the entire Brazilian coast in the intertidal zone, where it is collected and exported wet to the Japanese food market (Ramlov et al. 2011). G. domingensis is characterized by red, green, and brown phenotypes in natural populations (Pereira et al. 2012). This study aimed to evaluate the intraspecific differences of three color variants of $G$. domingensis in biomass yield, growth, and pigment by culturing them in a shrimp pond, an integrated organic system. The effect of different depths on photosynthetic response was also investigated.

\section{Materials and methods}

\section{Cultivation of Gracilaria}

The study was conducted in an organic shrimp farm (PRIMAR S/A) located in the margins of Guaraíras lagoon in the state of Rio Grande do Norte $\left(06^{\circ} 18^{\prime} \mathrm{S}-35^{\circ} 09^{\prime} \mathrm{W}\right)$ in northeastern Brazil. This facility has 40 ha of production of shrimp (Litopenaeus vannamei) and oysters (Crassostrea sp.) in organic IMTA. At Primar, shrimp culture is performed with a stocking density of 4 shrimp $\mathrm{m}^{-2}$. Production is estimated at $0.3 \mathrm{t} \mathrm{ha}^{-1} \mathrm{crop}^{-1}$. The water renewal rate of the pond (3.0 ha) was between 10 and $20 \%$ per day. No animal feed, antibiotics, fertilizers, aerators, or water circulation equipment was used. The experimental cultivation was carried out in a shrimp pond $\sim 1 \mathrm{~m}$ deep for 3 weeks. 
The color strains (red, green, and brown) of $G$. domingensis used in the experiment were collected at low tide in the intertidal zone of Rio do Fogo beach $\left(05^{\circ} 16^{\prime} \mathrm{S}-35^{\circ} 22^{\prime} \mathrm{W}\right)$. After collection, the strains were placed in isothermal boxes and transported to the farm where the experiment was performed. The three strains of $G$. domingensis were cultivated in two rectangular structures $(3.0 \mathrm{~m} \times 0.90 \mathrm{~m})$ made of PVC tubes and polyethylene ropes $(\varnothing 5 \mathrm{~mm})$. They were suspended at two depths (surface and $20 \mathrm{~cm}$ ) and anchored by stakes to the bottom of the shrimp pond. Each structure was subdivided into three units, each of which was separated by four ropes measuring $1 \mathrm{~m}$ in length. In each rope, ten seedlings $(20 \mathrm{~g})$ were inserted at $10 \mathrm{~cm}$ intervals. A cultivation unit contained 40 seedlings per strain, totaling approximately $800 \mathrm{~g}$ of fresh weight.

The strains were removed from their respective cultivation units and gently dried with paper towels to remove excess water every week. The seedlings were weighed and returned to the cultivation unit. The biomass was calculated as the difference between the final and initial measurement (fresh weight). The relative growth rate $\left(\%\right.$ day $\left.^{-1}\right)$ was estimated by the following formula: $\mathrm{RGR}=\ln \left(W_{\mathrm{f}} / W_{\mathrm{i}}\right) /\left(T_{\mathrm{f}}-T_{\mathrm{i}}\right) \times 100$, where $W_{\mathrm{i}}$ is the initial fresh weight $(\mathrm{g}), W_{\mathrm{f}}$ is final weight $(\mathrm{g})$, and $T_{\mathrm{f}}-T_{\mathrm{i}}$ is the time interval between the two measurements (De Casabianca et al. 1997).

Environmental parameters

Temperature $\left({ }^{\circ} \mathrm{C}\right)$, salinity, and $\mathrm{pH}$ were measured weekly with a multi-parameter probe (Horiba U10), and water transparency $(\mathrm{cm})$ was measured with a Secchi disk. Seawater samples were collected every week for the analysis of dissolved nutrients $\left(\mathrm{NH}_{4}{ }^{+}, \mathrm{NO}_{3}{ }^{-}, \mathrm{NO}_{2}{ }^{-}\right.$, and $\left.\mathrm{PO}_{4}{ }^{3-}\right)$ (Strickland and Parsons 1972). Daily data on the average irradiance (PAR 400-700 nm) were provided by the Center for Weather Prediction and Climate Studies (CPTEC) of the Spatial Research Institute (INPE) (http://www.cptec.inpe.br).

\section{Pigments}

All pigment-extraction procedures were performed under low-light and low-temperature $\left(0-10{ }^{\circ} \mathrm{C}\right)$ conditions. Apical segments of the algae were lyophilized (Liotop, L108) until a constant weight was obtained. The phycobiliprotein extraction (phycoerythrin and phycocyanin) was performed by macerating $90 \mathrm{mg}$ (dry weight) of algae in $\mathrm{N}_{2}$ (liquid). The macerated extract was suspended in $5 \mathrm{~mL}$ of $0.1-\mathrm{M}$ phosphate buffer (pH 6.8), homogenized, and kept at $4{ }^{\circ} \mathrm{C}$ for $12 \mathrm{~h}$ in the dark. After this period, the samples were centrifuged (20 min, 10,000g), and the supernatant absorbance was quantified by spectrophotometer (nm). The concentration was calculated according to the equations proposed by Beer and Eshel (1985). The chlorophyll $a$ concentration was determined using the same biomass utilized for the extraction of phycobiliproteins. This biomass was re-suspended in $1.8 \mathrm{~mL}$ of methanol:dimethylformamide (1:1). The homogenate was kept at $4{ }^{\circ} \mathrm{C}$ in the dark for $12 \mathrm{~h}$. The solution was centrifuged for $5 \mathrm{~min}$ at $10,000 \mathrm{rpm}$, the supernatant was collected, and absorbance (645-663 nm) was immediately measured with a spectrophotometer (Tecan infinite 2000). The concentration of chlorophyll $a$ was calculated according to Jeffrey and Humphrey (1975).

In vivo chlorophyll fluorescence measurements

The photosynthetic rate was evaluated in the field by chlorophyll fluorescence analysis using an underwater fluorometer with modulated pulse amplitude (Diving-PAM, Walz, Effeltrich, Germany). Measurements were performed in triplicate from 11 to $13 \mathrm{~h}$, and only the apex was used. The effective quantum yield of photosystem II (EQY) and the rate of electron transport (rETR) were determined for each sample. rETR was calculated as EQY $\times 0.5 \times$ PAR, where PAR is the actinic irradiance ( $\mu$ mol photons $\mathrm{m}^{-2} \mathrm{~s}^{-1}$ ) and 0.5 is a multiplying factor used, considering that a single electron transport requires the absorption of two quanta. Curves of photosynthesis versus irradiance (PI curves) based on the rETR values obtained at eight increasing levels of irradiance were generated. The parameters of photosynthetic efficiency $(\alpha)$, maximum photosynthesis $\left(\mathrm{rETR}_{\max }\right)$, and saturation $\left(I_{\mathrm{k}}\right)$ were calculated based on the PI curve by the equation of Platt et al. (1980). 
Statistical analysis

Data were initially analyzed using measures of central tendency (mean), measures of dispersion (standard deviation), and verification of the normality and homoscedasticity of the distribution before performing an ANOVA, considering the confidence level of $95 \%$. Abiotic parameters were each analyzed with one-factorial ANOVA. Biomass, RGR, pigments, and photosynthetic parameters were each analyzed by three-factorial ANOVA (depth $\times$ strain $\times$ time). The values with significant differences as determined by ANOVA were subjected to the Tukey post hoc test. All multiple comparisons were run with reported $95 \%$ confidence intervals, and $p$ values were Bonferroni-adjusted. The biomass, RGR, and abiotic parameters were subjected to Pearson correlation analysis. All statistical studies were performed using SPSS ${ }^{\circledR}$ software.

\section{Results}

Environmental parameters

Data on water characteristics during the experimental period are shown in Table 1. The temperature $\left(28-31{ }^{\circ} \mathrm{C}\right)$, salinity (21-23), and light (PAR) varied significantly throughout the experimental period $(p<0.05)$. However, the same was not observed for the water transparency values, which were constant during the study period $(20 \pm 0.0 \mathrm{~cm} ; p>0.05)$. The $\mathrm{pH}$ fluctuated between 8.3 and 8.5 , showing no significant differences during the experiment $(p>0.05)$.

The nutrient concentrations $\left(\mathrm{PO}_{4}{ }^{3-}, \mathrm{NO}_{3}{ }^{-}, \mathrm{NO}_{2}{ }^{-}\right.$, and $\mathrm{NH}_{4}{ }^{+}$) varied significantly over the time period $(p<0.05)$. The highest values of $\mathrm{PO}_{4}{ }^{3-}$ were recorded on the first day of the experiment $\left(0.83 \mu \mathrm{mol} \mathrm{L} \mathrm{L}^{-1}\right)$ and the lowest after 1 week $\left(0.54 \mu \mathrm{mol} \mathrm{L}{ }^{-1}\right)$. The average value for the study period was $0.75 \mu \mathrm{mol} \mathrm{L}{ }^{-1}$. Nitrate concentrations ranged from $0.67 \mu \mathrm{mol} \mathrm{L}^{-1}$ (minimum) at the beginning of the experiment to $1.41 \mu \mathrm{mol} \mathrm{L}{ }^{-1}$ (maximum) in the second week, with a mean of $1.04 \pm 0.22 \mu \mathrm{mol} \mathrm{L}{ }^{-1}$ during the experimental period. $\mathrm{NO}_{2}{ }^{-}$ had the lowest values in the first week $\left(0.25 \mu \mathrm{mol} \mathrm{L}^{-1}\right)$ and the highest in the second week of cultivation $(0.33 \mu \mathrm{mol} \mathrm{L}-1) . \mathrm{NH}_{4}^{+}$decreased significantly during the cultivation period, with the highest value of $3.69 \mu \mathrm{mol} \mathrm{L}{ }^{-1}$ at the beginning and the lowest value of $1.02 \mu \mathrm{mol} \mathrm{L}^{-1}$ at the end of the experiment. The average value of this nutrient was $1.90 \pm 0.74 \mu \mathrm{mol} \mathrm{L}{ }^{-1}$.

Biomass and growth

Gracilaria domingensis showed a similar biomass pattern at both depths $(F=0.28 ; p>0.05)$. The results showed a significant increase of the biomass during the first 2 weeks of the experiment for the three strains

Table 1 Chemical and physical characteristics of the water column in shrimp pond during the study period (range and mean \pm standard deviation, $n=9$ )

\begin{tabular}{|c|c|c|c|c|}
\hline \multirow[t]{2}{*}{ Environmental parameters } & \multirow[t]{2}{*}{ Range } & \multirow[t]{2}{*}{ Mean + SD } & \multicolumn{2}{|c|}{ ANOVA } \\
\hline & & & $F$ & $p$ \\
\hline Water temperature $\left({ }^{\circ} \mathrm{C}\right)$ & $28.0-31.0$ & $29.25 \pm 1.2$ & 475 & $<0.001$ \\
\hline Salinity & $21-23$ & $22 \pm 0.81$ & 200 & $<0.001$ \\
\hline $\mathrm{pH}$ & $8.3-8.5$ & $8.39 \pm 0.11$ & 10.38 & 0.016 \\
\hline Dissolved oxygen $\left(\mathrm{mg} \mathrm{L}^{-1}\right)$ & $6.4-9.9$ & $7.28 \pm 0.06$ & 496.75 & $<0.01$ \\
\hline Water transparency $(\mathrm{cm})$ & $20-20$ & $20 \pm 0.0$ & 0 & $>0.05$ \\
\hline $\operatorname{PAR}\left(\mu \mathrm{mol}\right.$ photon $\left.\mathrm{m}^{-2} \mathrm{~s}^{-1}\right)$ & $1380-874$ & $1231 \pm 117$ & 3.72 & $<0.01$ \\
\hline Rainfall (mm) & $0.25-13.21$ & $0.75 \pm 0.14$ & 7.05 & $>0.05$ \\
\hline $\mathrm{PO}_{4}\left(\mu \mathrm{mol} \mathrm{L}{ }^{-1}\right)$ & $0.54-0.83$ & $0.75 \pm 0.13$ & 504.6 & $<0.001$ \\
\hline $\mathrm{NH}_{4}\left(\mu \mathrm{mol} \mathrm{L}{ }^{-1}\right)$ & $1.02-3.69$ & $1.90 \pm 0.74$ & 16.93 & $>0.05$ \\
\hline $\mathrm{NO}_{3}\left(\mu \mathrm{mol} \mathrm{L}{ }^{-1}\right)$ & $0.67-1.41$ & $1.04 \pm 0.22$ & 36.69 & $<0.001$ \\
\hline $\mathrm{NO}_{2}\left(\mu \mathrm{mol} \mathrm{L}{ }^{-1}\right)$ & $0.25-0.33$ & $0.29 \pm 0.03$ & 61.17 & $<0.001$ \\
\hline
\end{tabular}



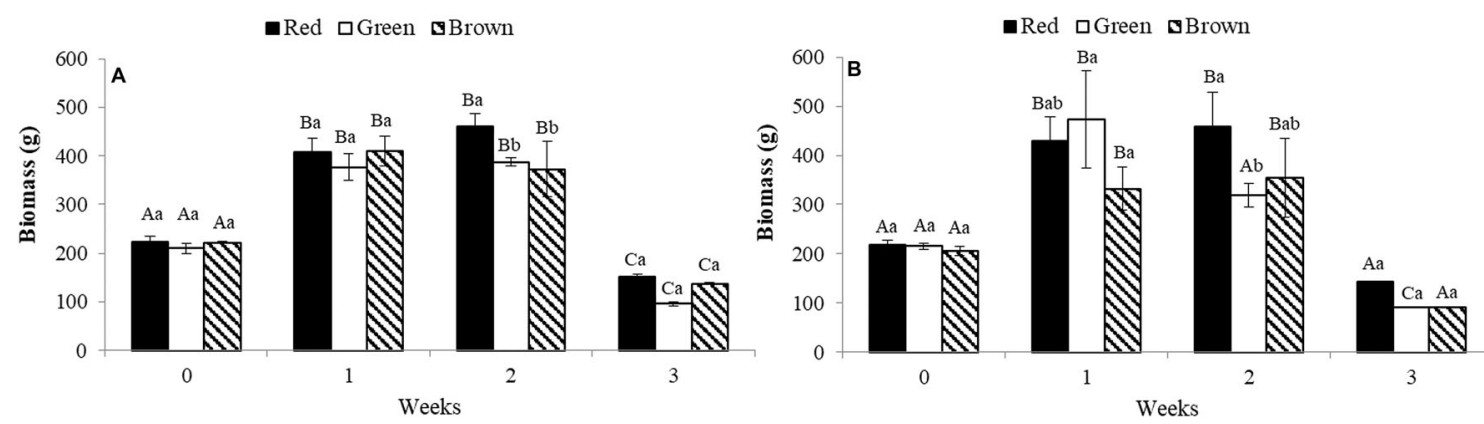

Fig. 1 Mean biomass of the three color strains (red, green, and brown) of G. domingensis cultivated in a shrimp pond at two depths: surface (a) and $20 \mathrm{~cm}$ (b). Different letters indicate significant differences. Uppercase letters specify differences throughout the experimental period and lowercase letters the differences among treatments. Data are given as mean $\pm \mathrm{SD}$ $(n=4)$

cultivated at the surface (Fig. 1a) and $20 \mathrm{~cm}$ depths (Fig. 1b). After this period, there was a marked and significant $(p<0.001)$ reduction of algal biomass $(70 \%)$. The biomass means for the experimental period were $311 \pm 147.15,267.5 \pm 140.07$, and $285.62 \pm 127.72$ for red, green, and brown strains, respectively, on the surface, and $311.93 \pm 155.87,275.06 \pm 161.91$, and $245.93 \pm 121.97$ for red, green, and brown strains, respectively, at a depth of $20 \mathrm{~cm}$.

The RGR showed the same trend, with the highest values recorded during the first 2 weeks. The RGR values were $10.03 \pm 1.67 \% \mathrm{day}^{-1}$ (red), $9.70 \pm 1.47 \% \mathrm{day}^{-1}$ (green), and $10.15 \pm 1.11 \% \mathrm{day}^{-1}$ (brown) on the surface (Fig. 2a), and $11.25 \% \pm 1.50$ day $^{-1}$ (red), $12.76 \% \pm 3.96$ day $^{-1}$ (green), and $7.86 \% \pm 1.75$ day $^{-1}$ (brown) at a depth of $20 \mathrm{~cm}$ (Fig. 2b). The last cultivation week was characterized by biomass loss and no growth for the three strains. The mean growth rates for the entire period were $4.25 \pm 5.45,3.07 \pm 6.34$, and $3.59 \pm 5.66 \% \mathrm{day}^{-1}$ for the red, green, and brown strains, respectively, on the surface, and $4.63 \pm 6.02$, $3.38 \pm 8.02-$, and $2.16 \pm 5.78 \% \mathrm{day}^{-1}$ for the red, green, and brown strains, respectively, at a depth of $20 \mathrm{~cm}$.

Positive correlations were found between RGR and temperature on the surface (red, $r=0.55$; green, $r=0.54$; brown, $r=0.64)$ and at $20 \mathrm{~cm}$ for the red $(r=0.58)$ and green $(r=0.68)$ strains. There was also a positive correlation between $\mathrm{NH}_{4}{ }^{+}$and RGR for the red $(r=0.79)$, green $(r=0.81)$, and brown $(r=0.83)$ strains cultivated on the surface, as well as at a depth of $20 \mathrm{~cm}$ (red, $r=0.83$; green, $r=0.82$; brown, $r=0.77)$. Negative correlations were observed between $\mathrm{RGR}$ and $\mathrm{PO}_{4}{ }^{3-}$ for the three strains on the surface (red, $r=-0.82$; green, $r=-0.80$; brown, $r=-0.87$ ) and at a depth of $20 \mathrm{~cm}$ (red, $r=-0.84$; green, $r=-$ 0.87 ; brown, $r=-0.75$ ).

Pigments and photosynthesis

Significant differences in phycoerythrin content were observed among the strains $(F=130.96 ; p<0.001)$, with the highest values of phycoerythrin recorded in the red and brown strains $(p<0.001)$, and the lowest values in the green strain (Fig. 3). The phycocyanin (Fig. 4) content did not change between strains $(p>0.05)$. The concentration of chlorophyll $a$ showed the same trend as the phycoerythrin and phycocyanin, with the highest values recorded at $20 \mathrm{~cm}$. The highest value of chlorophyll $a$ was found in the red and green strains $(p<0.001)$ (Fig. 5).

The photosynthetic characteristics of each strain tested at different depths are shown in Table 2. There was no significant difference in the $\mathrm{rETR}_{\max }$ at different depths $(p>0.05)$. However, there were differences between the red and brown strains grown at $20 \mathrm{~cm}(F=5.18 ; p<0.05)$, with the highest value found in the brown strain. The photosynthetic efficiency $(\alpha)$ varied with depth only for the green strain, and it was higher on the surface $(F=11.06 ; p<0.001)$. There was a significant difference in $\alpha$ among the strains grown on the surface, and the green strain showed the highest value $(F=3.84 ; p<0.05)$. There was no significant difference in $I_{\mathrm{k}}$ and EQY at different depths or among strains $(p>0.05)$. 

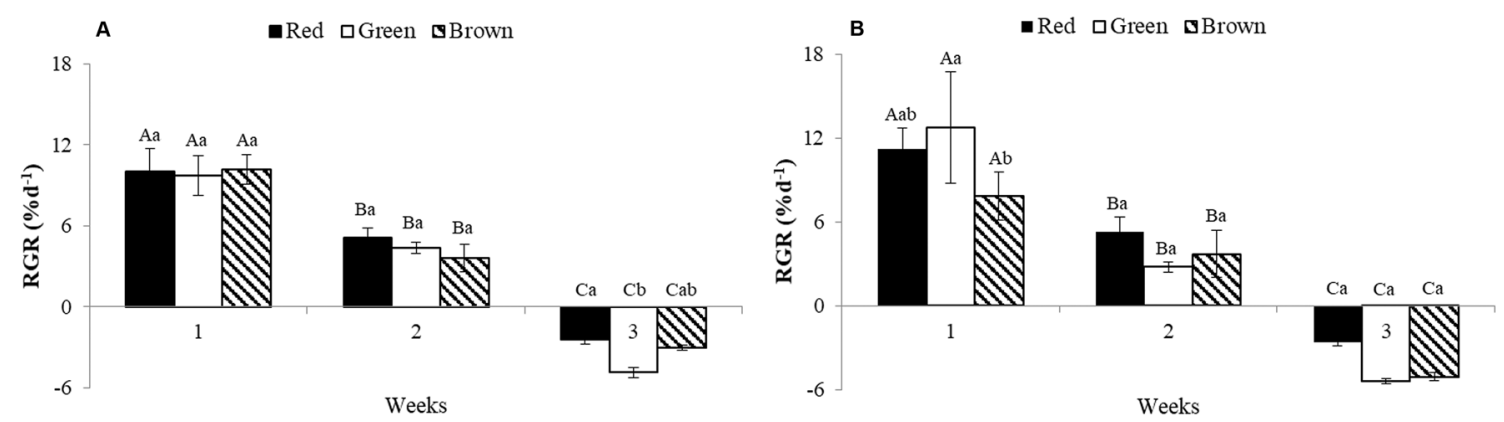

Fig. 2 Mean RGR of the three color strains (red, green, and brown) of G. domingensis cultivated in a shrimp pond at two depths: surface (a) and $20 \mathrm{~cm}$ (b). Different letters indicate significant differences. Uppercase letters specify differences throughout the experimental period and lowercase letters the differences among treatments. Data are given as mean $\pm \operatorname{SD}(n=4)$

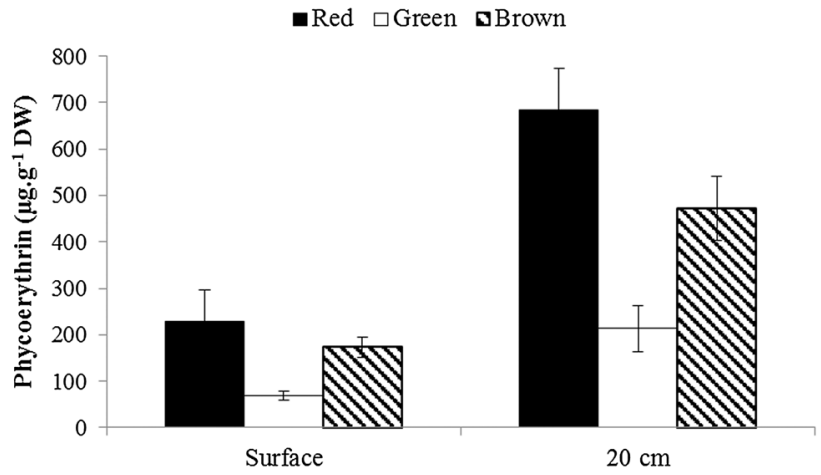

Fig. 3 Phycoerythrin contents of the three color strains (red, green, and brown) of G. domingensis grown in shrimp ponds at two depths (surface and $20 \mathrm{~cm})$. Data are given as mean $\pm \mathrm{SD}(n=3)$

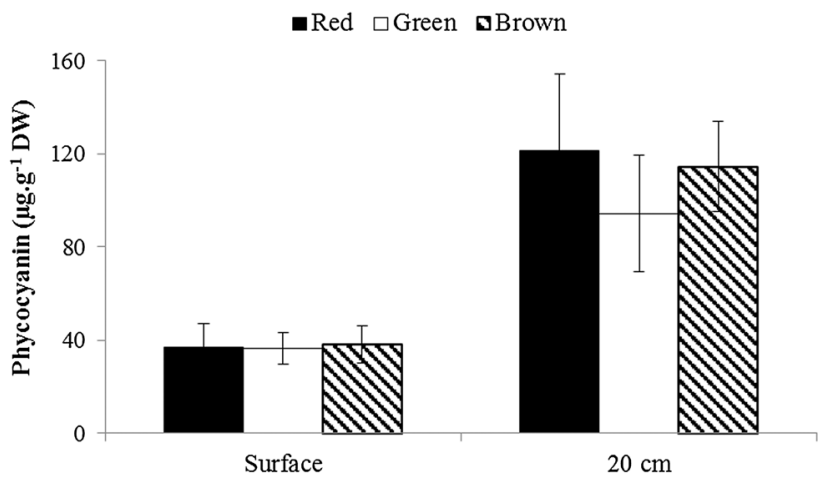

Fig. 4 Phycocyanin contents of the three color strains (red, green, and brown) of G. domingensis grown in shrimp ponds at two depths (surface and $20 \mathrm{~cm})$. Data are given as mean $\pm \mathrm{SD}(n=3)$

\section{Discussion}

In this study, the three color variants of $G$. domingensis showed very high growth rates, above all in the first 2 weeks of culture, reaching yields above $100 \%$ in some cases. The high growth values achieved by the three strains in the first weeks of the experiment are in agreement with previous results with other Gracilaria species (Nelson et al. 2001; Yang et al. 2006; Samocha et al. 2015). The mean RGR of the three strains of $G$. domingensis obtained for the whole period $\left(2-4 \%\right.$ day $\left.^{-1}\right)$ was higher than those found in other Gracilaria species tested in shrimp ponds in Brazil (Marinho-Soriano et al. 2002, 2009; Oliveira et al. 2012). This high growth obtained for the morphotypes of $G$. domingensis may be explained by differences of water quality 


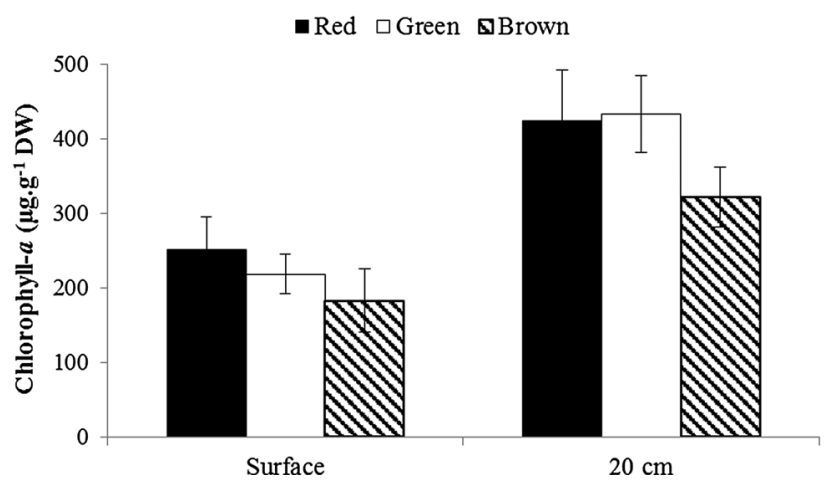

Fig. 5 Chlorophyll- $a$ content of the three color strains (red, green, and brown) of G. domingensis grown in shrimp ponds at two depths (surface and $20 \mathrm{~cm})$. Data are given as mean $\pm \mathrm{SD}(n=3)$

Table 2 Photosynthetic parameters of the three color strains (red, green, and brown) of Gracilaria domingensis grown in shrimp ponds at two depths (surface and $20 \mathrm{~cm}$ )

\begin{tabular}{|c|c|c|c|}
\hline & \multicolumn{3}{|l|}{ Mean \pm SD } \\
\hline & Red & Green & Brown \\
\hline \multicolumn{4}{|l|}{ Shrimp pond-Surface } \\
\hline Photosynthetic efficiency $(\alpha)^{\mathrm{a}}$ & $0.13 \pm 0.02$ & $0.26 \pm 0.07$ & $0.17 \pm 0.03$ \\
\hline $\mathrm{rETR}_{\max }^{\mathrm{a}}$ & $14.8 \pm 3.7$ & $20.1 \pm 3.0$ & $21.4 \pm 6.85$ \\
\hline$I_{\mathrm{k}}^{\mathrm{b}}$ & $116.0 \pm 48.6$ & $81.1 \pm 22.2$ & $134.2 \pm 76.9$ \\
\hline Effective quantum yield (EQY) & $0.471 \pm 0.05$ & $0.560 \pm 0.04$ & $0.521 \pm 0.07$ \\
\hline \multicolumn{4}{|l|}{ Shrimp pond $-20 \mathrm{~cm}$} \\
\hline Photosynthetic efficiency $(\alpha)^{\mathrm{a}}$ & $0.10 \pm 0.02$ & $0.12 \pm 0.01$ & $0.14 \pm 0.05$ \\
\hline $\mathrm{rETR}_{\max }^{\mathrm{a}}$ & $8.9 \pm 0.73$ & $14.9 \pm 4.58$ & $21.9 \pm 8.71$ \\
\hline$I_{\mathrm{k}}^{\mathrm{b}}$ & $94.5 \pm 27.07$ & $129.7 \pm 37.59$ & $168.4 \pm 80.03$ \\
\hline Effective quantum yield (EQY) & $0.462 \pm 0.17$ & $0.629 \pm 0.03$ & $0.635 \pm 0.02$ \\
\hline
\end{tabular}

Data represent means and standard deviations of $n=5$

SI measurements: ${ }^{\mathrm{a}}\left(\mu \mathrm{mol}\right.$ electrons $\left.\mathrm{m}^{-2} \mathrm{~s}^{-1}\right){ }^{\mathrm{b}}\left(\mu \mathrm{mol}\right.$ photons $\mathrm{m}^{-2} \mathrm{~s}^{-1}$ )

characteristics, where the experiments were carried out (intensive and organic aquaculture). In general, intensive aquaculture is characterized by high nutrient concentration, organic matter, suspended solids, and low dissolved oxygen concentration, whereas organic aquaculture is closely associated with better water quality (e.g., lower nutrient levels, suspended matter, and turbidity).

High values of biomass and growth rates are desirable in an integrated aquaculture application. In this study, the growth rate decreased for the three color strains at the end of the experiment. Environmental factors, such as nutrients, water motion, and turbidity, are known to affect the growth of seaweed negatively in shrimp ponds (Marinho-Soriano et al. 2002). However, no changes in water transparency $(20 \mathrm{~cm})$ or water motion were observed throughout the study. Besides that, the RGR of all strains showed a positive correlation with $\mathrm{NH}_{4}{ }^{+}$indicating no limitation by nitrogen. A possible explanation for the biomass loss and reduction of growth rate observed at the end of the experiment is the long exposure of seaweed to atmospheric conditions and its desiccation during the water exchange of the ponds. During this period, there was a failure in the farm's pumping system, which caused a drastic reduction in the volume of water in the pond and the exposure of seaweeds to sunlight for several hours. The effects of sun exposure and dehydration during the emersion could have caused physiological stress and subsequent biomass loss (70\%). Indeed, aerial exposure results in energetic cost and reduces available resources for growth, such as nitrogen and inorganic carbon (Lobban and Harrison 1997).

The red strain at both depths showed better performance in biomass and RGR than did the green and brown strains. A similar pattern in growth rate was also described in the red strain by Faria and Plastino (2016) for $G$. 
caudata and Veeragurunathan et al. (2016) for G. debilis and G. edulis. The fact that the red strain exhibited the highest growth at both depths indicates that it is better adapted to the environmental conditions of the shrimp ponds. The performance of this strain may be associated with intrinsic genetic characteristics that result in different metabolic characteristics. In general, the red strain has a higher concentration of protein and phycoerythrin (Yokoya et al. 2007). These two components play an important role in nitrogen storage, and are the primary pools of metabolized nitrogen when environmental nitrogen concentrations are reduced. Moreover, the fact that the red strain synthesizes more phycoerythrin makes it more competitive in capturing solar energy and performing photosynthesis (Pereira et al. 2012). This ability contributes to higher growth and thus better environmental performance.

Higher concentrations of the photosynthetic pigments chlorophyll $a$ and phycobiliproteins were registered in algae grown at $20 \mathrm{~cm}$. This result is in agreement with previous studies (Eswaran et al. 2002; MarinhoSoriano 2012; Pereira et al. 2012), which also observed an increase in the pigment concentration associated with a decrease in irradiance. This increment in pigment concentration is related to an increase in the size of the light-harvesting complex and the number of photosystems, resulting in an amplified ability to collect incident light and convert it into energy. This acclimation to low irradiance may be shown by EQY values presented by the strains when grown at a depth of $20 \mathrm{~cm}$. However, under high-irradiance conditions, the algae can optimize their photosynthetic apparatus by reducing the number of photosystems and light-harvesting complexes, and avoiding superexcitation and the formation of free radicals.

In addition, the differences in the photosynthetic efficiency and in the phycoerythrin concentration highlight distinct patterns for the chromatic strains of $G$. domingensis, which could be attributed to intraspecific variation. The decline in the green strain's photosynthetic efficiency with increasing depth and its low phycoerythrin content may indicate that this strain exhibits characteristics of sun-adapted plants and that the strains have different light requirements. Similar results were observed by Yokoya et al. (2007), in whose study the brown strain of Hypnea musciformis, which has high phycoerythrin content, presented characteristics of shade-adapted plants, whereas the light-green strain, a phycoerythrin-deficient strain, presented characteristics of sun-adapted plants.

Finally, the results obtained in this study indicate that the three strains can be cultivated in an organic system and that $G$. domingensis can be tested as a candidate for future commercial cultivation. Moreover, the integration of this species with shrimp may bring additional benefits to producers and for the environment.

Acknowledgements This study was supported by Conselho Nacional de Desenvolvimento Científico Tecnológico (CNPq). Special thanks to Mr. Alexandre Wainberg (in memoriam) for allowing the study to be carried out at the PRIMAR shrimp farm.

Open Access This article is distributed under the terms of the Creative Commons Attribution 4.0 International License (http:// creativecommons.org/licenses/by/4.0/), which permits unrestricted use, distribution, and reproduction in any medium, provided you give appropriate credit to the original author(s) and the source, provide a link to the Creative Commons license, and indicate if changes were made.

\section{References}

Ayres-Ostrock LM, Plastino EM (2014) Effects of UV-B radiation on growth rates, pigment content and ultrastructure of red (wild type), greenish-brown and green strains of Gracilaria birdiae (Gracilariales, Rhodophyta). Eur J Phycol 49:197-212

Barceló-Villalobos M, Figueroa FL, Korbee N, Álvarez-Gómez F, Abreu MH (2017) Production of mycosporine-like amino acids from Gracilaria vermiculophylla (Rhodophyta) cultured through one year in an integrated multi-trophic aquaculture (IMTA) System. Mar Biotechnol 19:246-254

Barrington K, Ridler N, Chopin T, Robinson S, Robinson B (2010) Social aspect of the sustainability of integrated multi-trophic aquaculture. Aquacult Int 18:201-211

Beer SS, Eshel A (1985) Determining phycoerythrin and phycocyanin concentrations in aqueous crude extracts of red algae. Aust J Mar Fresh Res 36:785-792

Bergleiter S (2011) Organic aquaculture_from a "nice niche" to the "whole cake". Ecol Farm 30:14-17

Buchholz CM, Krause G, Buck BH (2012) Seaweed and man. In: Wiencke C, Bischof K (eds) Seaweed biology. Springer, Berlin, pp 471-493

Chopin T, Robinson SMC, Troell M, Neori A, Buschmann AH, Fang J (2008) Multitrophic integration for sustainable marine aquaculture. In: Jørgensen SE, Fath BD (eds) Encyclopedia of ecology: ecological engineering. Elsevier, Oxford, pp 2463-2475

De Casabianca ML, Marinho-Soriano E, Laugier T (1997) Growth of Gracilaria bursa-pastoris in a Mediterranean lagoon: Thau, France. Bot Mar 40:29-37 
Eswaran K, Mairh OP, Subba Rao PV (2002) Inhibition of pigments and phycocolloid in a marine red algae Gracilaria edulis by ultraviolet-B radiation. Biol Plant 45:157-159

Faria AVF, Plastino EM (2016) Physiological assessment of the mariculture potential of a Gracilaria caudata (Gracilariales, Rhodophyta) variant. J Appl Phycol 28:2445-2452

Harrison PJ, Hurd CL (2001) Nutrient physiology of seaweeds: application of concepts to aquaculture. Cah Biol Mar 42:71-82

Jefferey SW, Humphrey GF (1975) New spectrophotometric equations for determining chlorophylls a, b, $c_{1}$, and $c_{2}$ in higher plants, algae, and natural phytoplankton. Biochem Physiol Pflanzen 167:191-194

Lobban CS, Harrison PJ (1997) Seaweed ecology and physiology. Cambridge University Press, New York

Marinho-Soriano E (2012) Effect of depth on growth and pigment contents of the macroalgae Gracilaria bursa-pastoris. Braz $\mathbf{J}$ Pharmacog 22:730-735

Marinho-Soriano E (2017) Historical context of commercial exploitation of seaweeds in Brazil. J Appl Phycol 29:665-671

Marinho-Soriano E, Morales C, Moreira WSC (2002) Cultivation of Gracilaria (Rhodophyta) in shrimp pond effluents in Brazil. Aquac Res 33:1081-1086

Marinho-Soriano E, Panucci RA, Carneiro MAA, Pereira DC (2009) Evaluation of Gracilaria caudata J. Agardh for bioremediation of nutrients from shrimp farming wastewater. Bioresour Technol 100:6192-6198

Nelson G, Glenn EP, Conn J, Moore D, Walsh T, Akutagawa M (2001) Cultivation of Gracilaria parvispora (Rhodophyta) in shrimp-farm effluent and floating cages in Hawaii: a two-phase polyculture system. Aquaculture 193:239-248

Neori A, Chopin T, Troell M, Buschmann AH, Kraemer GP, Halling C, Shpigel M, Yarish C (2004) Integrated aquaculture: rationale, evolution and state of the art emphasizing seaweed biofiltration in modern mariculture. Aquaculture 231:361-391

Oliveira VP, Freire FAM, Marinho-Soriano E (2012) Influence of depth on the growth of the seaweed Gracilaria birdiae (Rhodophyta) in a shrimp pond. Braz J Aquat Sci Tech 16:33-39

Pereira DC, Trigueiro TG, Colepicolo P, Marinho-Soriano E (2012) Seasonal changes in the pigment composition of natural population of Gracilaria domingensis (Gracilariales, Rhodophyta). Braz J Pharmacog 22:874-880

Platt T, Gallegos CL, Harrison WG (1980) Photoinhibition of photosynthesis in natural assemblages of marine phytoplankton. J Mar Res 38:687-701

Ramlov F, Souza JMC, Faria AVF, Maraschin M, Horta PA, Yokoya NS (2011) Growth and accumulation of carotenoids and nitrogen compounds in Gracilaria domingensis (Kütz.) Sonder ex Dickie (Gracilariales, Rhodophyta) cultured under different irradiance and nutrient levels. Braz J Pharmacog 21:255-261

Samocha TM, Fricker J, Ali AM, Shpigel M, Neori A (2015) Growth and nutrient uptake of the macroalga Gracilaria tikvahiae cultured with the shrimp Litopenaeus vannamei in an integrated multi-trophic aquaculture (IMTA) system. Aquaculture 446:263-271

Strickland JDH, Parsons TR (1972) A practical handbook of seawater analysis, 2nd edn. Fisheries Research Board of Canada, Ottawa

Ursi S, Costa VL, Hayashi L, Pereira RTL, Paula EJ, Plastino EM (2013) Intraspecific variation in Gracilaria birdiae (Gracilariales, Rhodophyta): growth, and agar yield and quality of color strains under aquaculture. Bot Mar 56:241-248

Veeragurunathan V, Prasad K, Singh N, Malarvizhi J, Mandal SK, Mantri VA (2016) Growth and biochemical characterization of green and red strains of the tropical agarophytes Gracilaria debilis and Gracilaria edulis (Gracilariaceae, Rhodophyta). J Appl Phycol 28:3479-3489

Wu H, Huo Y, Han F, Liu Y, He P (2015) Bioremediation using Gracilaria chouae co-cultured with Sparus macrocephalus to manage the nitrogen and phosphorous balance in an IMTA system in Xiangshan Bay, China. Mar Pollut Bull 91:272-279

Yang YF, Fei XG, Song JM, Hu HY, Wang GC, Chung IK (2006) Growth of Gracilaria lemaneiformis under different cultivation conditions and its effects on nutrient removal in Chinese coastal waters. Aquaculture 254:248-255

Yarish C, Pereira CR (2008) Mass production of marine macroalgae. In: Jørgensen SE, Fath BD (eds) Encyclopedia of Ecology: Ecological Engineering. Elsevier, Oxford, pp 2236-2247

Yokoya NS, Necchi O, Martins AP, Gonzalez SF, Plastino EM (2007) Growth responses and photosynthetic characteristics of wild and phycoerythrin-deficient strains of Hypnea musciformis (Rhodophyta). J Appl Phycol 19:197-205

Yu Z, Robinson SM, Xia J, Sun H, Hu C (2016) Growth, bioaccumulation and fodder potentials of the seaweed Sargassum hemiphyllum grown in oyster and fish farms of South China. Aquaculture 464:459-468 